\title{
The clinical and laboratorial evaluation of transdermal ketamine, fentanyl, clonidine or their combination in chronic low back pain
}

\author{
Avaliação clínica e laboratorial da cetamina transdérmica, do \\ fentanil transdérmico, da clonidina transdérmica ou suas associações \\ na dor lombar crônica
}
Evaluación clínica y de laboratorio de cetamina transdérmica, del fentanyl transdérmico, de la clonidina transdérmica o de sus asociaciones en el dolor lumbar crónico

\author{
Gabriela Rocha Lauretti ${ }^{1}$ \\ Márcio Matsumoto ${ }^{2}$ \\ Anita Leocádia de Mattos ${ }^{3}$ \\ Vera Lanchote ${ }^{4}$ \\ Newton Lindolfo Pereira ${ }^{5}$
}

\section{ABSTRACT}

Objectives: chronic low back pain may result in central sensitization, with involvement of different receptors. The aim of this study was to evaluate the analgesic action of transdermal (T) ketamine (a NMDA antagonist), clonidine (an $\alpha 2$-agonist), fentanyl (an opioid agonist), or their combination in chronic low back pain. Methods: after the institutional approval and informed consent signature, 54 patients were prospectively randomized into 6 groups. Each patient had two of the T preparations applied in different arms. The effect of either T ketamine $(1 \mathrm{mg} / \mathrm{h})$, $\mathrm{T}$ clonidine $(25 \mu \mathrm{g} / \mathrm{h})$ or $\mathrm{T}$ fentanyl $(25 \mu \mathrm{g} / \mathrm{h})$, combined with $\mathrm{T}$ placebo (CloG, KetG and FenG); or the combination of $\mathrm{T}$ ketamine and clonidine
\end{abstract}

\section{RESUMO}

Objetivos: a dor lombar crônica pode resultar em sensibilização central, com a participação de diferentes tipos de receptores. O objetivo deste estudo foi avaliar a ação analgésica por via transdérmica $(\mathrm{T})$ do fentanil, cetamina, clonidina ou suas associações para o alívio da dor lombar crônica. Métodos: após aprovação do Comitê de Ética em Pesquisa e assinatura do termo de consentimento livre e esclarecido, 54 pacientes foram avaliados de forma prospectiva, aleatória e duplamente-encoberta, sendo divididos em 6 grupos. Cada paciente recebeu duas preparações por via transdérmica, aplicadas em braços diferentes ( $\mathrm{T}$ cetamina $(1 \mathrm{mg} / \mathrm{h}), \mathrm{T}$ clonidina $(25$ $\mu \mathrm{g} / \mathrm{h})$ ou $\mathrm{T}$ fentanil $(25 \mu \mathrm{g} / \mathrm{h})$, associados a $\mathrm{T}$ placebo (CloG, CetG and

\section{RESUMEN}

Objetivos: el dolor lumbar crónico puede resultar en sensibilización central, con la participación de diferentes tipos de receptores. El objetivo de este estudio fue evaluar la acción analgésica por vía transdérmica (T) del fentanyl, cetamina, clonidina o sus asociaciones en dolor lumbar crónico. Métodos: después de la aprobación por el Comité de Ética en Investigación y Consentimiento, 54 pacientes fueron evaluados de forma prospectiva, aleatoria e duplamenteciego siendo divididos en seis grupos. Cada paciente recibió dos preparaciones por vía transdérmica, aplicadas en brazos diferentes (T cetamina $(1 \mathrm{mg} / \mathrm{h})$, T clonidina $(25 \mu \mathrm{g} / \mathrm{h})$ o $T$ fentanyl $(25 \mu \mathrm{g} / \mathrm{h})$, asociados a $T$ placebo (CloG, CetG y FenG); o la

\footnotetext{
Study carried out at Clínica para o Tratamento da Dor of the Hospital das Clínicas of the Faculdade de Medicina de Ribeirão Preto of Universidade de São Paulo USP - Ribeirão Preto (SP), Brazil.

'Associate Professor at Faculdade de Medicina de Ribeirão Preto of Universidade de São Paulo - USP- Ribeirão Preto (SP), Brazil.

${ }^{2}$ Postgraduate Student of Orthopedic Area at Faculdade de Medicina de Ribeirão Preto of Universidade de São Paulo - USP- Ribeirão Preto (SP), Brazil.

${ }^{3}$ Assistant Professor at Faculdade de Medicina de Ribeirão Preto of Universidade de São Paulo - USP - Ribeirão Preto (SP), Brazil.

${ }^{4}$ Professor at Faculdade de Ciências Farmacêuticas de Ribeirão Preto of Universidade de São Paulo - USP - Ribeirão Preto (SP), Brazil.

${ }^{5}$ Assistant Professor at Faculdade de Ciências Farmacêuticas de Ribeirão Preto of Universidade de São Paulo - USP - Ribeirão Preto (SP), Brazil. 
(Ket-CloG), $\mathrm{T}$ fentanyl and ketamine (Fen-KetG), or T fentanyl and clonidine (Fen-CloG) was searched for pain and adverse effects. Pain was evaluated by: 1) VAS pain scores, and 2) noradrenaline plasma levels at 0 -h (just prior to $\mathrm{T}$ application), 3- and 6-h after the $\mathrm{T}$ application of two medications, by HPLC. Results: clinically, the pain VAS score at 6 -h was smaller in comparison to the 0 -h in all groups $(\mathrm{p}<0.02)$, and lower when compared to the Fen-CloG and Fen-KetG at the 6-h in relation to the administration of each correspondent $\mathrm{T}$ drug alone $(\mathrm{p}<0.05)$. The laboratorial data revealed that administration of $\mathrm{T}$ fentanyl alone $(\mathrm{FenG})$ resulted in plasma noradrenaline decrease at $6-\mathrm{h}(\mathrm{p}<0.01)$, while the association of $\mathrm{T}$ fentanyl with clonidine resulted in plasma noradrenaline decrease at 3- and 6-h as compared to the others $(\mathrm{p}<0.01)$. The combination of both $\mathrm{T}$ ketamine and clonidine (Ket-CloG) did not result in a better analgesic profile and resulted in excessive sedation during the evaluation $(\mathrm{p}<0.02)$. Conclusions: all the studied drugs resulted in clinical analgesia (VAS) at 6-h. However, T fentanyl analgesia was corroborated by lower plasma noradrenaline levels at 6-h when applied alone or at 3-h when combined with $\mathrm{T}$ clonidine.
FenG); ou a associação de $\mathrm{T}$ cetamina e clonidina (Cet-CloG), $\mathrm{T}$ fentanil e cetamina (Fen-CetG), ou $\mathrm{T}$ fentanil e clonidina (Fen-CloG). A analgesia e a incidência de efeitos adversos foram avaliadas. A analgesia foi avaliada com: 1) VAS-cm, e 2) níveis plasmáticos de noradrenalina às 0 -h (antes da aplicação T), 3- e 6-h após a aplicação T, com HPLC. Resultados: clinicamente, os valores de VAS as 6-h foram menores comparados ao tempo de 0-h para todos os grupos $(\mathrm{p}<0,02)$, e menores para o Fen-CloG e Fen-CetG às 6-h em relação à administração de cada droga $T$ isolada $(p<0,05)$. A administração de fentanil $\mathrm{T}$ (FenG) resultou em diminuição dos níveis de noradrenalina plasmática às 6-h $(p<0,01)$, enquanto a associação de fentanil $\mathrm{T}$ com clonidina $\mathrm{T}$ resultou em diminuição de noradrenalina plasmática às 3-h e 6-h em comparação aos demais grupos $(\mathrm{p}<0.01)$. A combinação de cetamina e clonidina (Cet-CloG) não ofereceu melhor perfil analgésico e resultou em sedação excessiva $(p<0,02)$. Conclusões: todos os grupos apresentaram melhora clínica (VAS) da dor às 6-h. Entretanto, somente quem recebeu fentanil $\mathrm{T}$ apresentou níveis plasmáticos de noradrenalina mais baixos às 6-h (quando combinado com placebo) e às $3-\mathrm{h}$ quando associado à clonidina $\mathrm{T}$. asociación de $T$ cetamina y clonidina (Cet-CloG), $T$ fentanyl y cetamina (Fen-CetG), o $T$ fentanyl y clonidina (fen-CloG). La analgesia y la incidencia de efectos adversos fueron evaluadas. La analgesia fue evaluada con: 1) VAS-cm, y 2) niveles plasmáticos de noradrenalina a las 0 hora (antes de la aplicación T), tres y seis horas después de la aplicación T, con HPLC. Resultados: clínicamente los valores de VAS a las seis horas fueron menores comparados a 0 hora para todos los grupos $(p<0,02)$, y menores para el Fen-CloG y Fen-CetG a las seis horas después de la administración de cada droga T aislada $(p<0,05)$. La administración de fentanyl $T$ (Feng) resultó en disminución de los niveles de noradrenalina plasmática a las seis horas $(p<0,01)$. La combinación de cetamina y clonidina (Cet-CloG) no ofreció mejor perfil analgésico y resultó en sedación excesiva ( $p<0,02)$. Conclusiones: todos los grupos presentaron mejoría clínica (VAS) del dolor a las seis horas. Sin embargo, solamente quien recibió fentanyl $T$ presentó menores niveles plasmáticos de noradrenalina a las seis horas (cuando combinado con placebo) y a las tres horas cuando asociado con clonidina $T$.

DESCRITORES: Analgesia epidural; Analgésicos/administração $\&$ dosagem; Clonidina/ administração \& dosagem; Ketamina/administração $\&$ dosagem; Fentanila/ administração \& dosagem; Administração cutânea; Dor lombar/quimioterapia
DESCRIPTORES: Analgesia epidural; Analgésicos/ administración \& dosificación; Clonidina/administración \& dosificación; Cetamina/ administración \& dosificación; Fentanilo/administración \& dosificación; Administración cutánea; Dolor de la región lumbar/quimioterapia

\section{INTRODUCTION}

Persistent nociception following low back pain may lead to transcriptional and translational changes in the spinal cord and brain, resulting in central sensitization and pain. It involves different spinal processes, and the participa- tion of N-methyl- $D$-aspartate (NMDA) ${ }^{1}, \alpha 2$-adrenergic ${ }^{2}$ and opioid receptors ${ }^{3}$ may play a role. The purpose of this paper was to evaluate the analgesic action of transdermal (T) ketamine (a NMDA antagonist), clonidine (an $\alpha 2$ agonist), fentanyl (an opioid agonist), or their combina- 
tion in chronic non-radicular low back pain. The study was conducted and limited to duration of assessment because of our interest in defining the best drugs association, in order to direct us for future and long-time evaluation studies. Plasma measurement of noradrenaline, a predictive stress neurotransmitter ${ }^{4}$, was carried out to corroborate any analgesic effect from the T systems applied.

\section{METHODS}

After the Ethics Committee approval and written informed consent signature, 54 ASA status II patients suffering from chronic low back pain were computer-randomized to one of six groups and prospectively evaluated using a placebocontrolled double-blind design to examine analgesia and adverse effects $(n=9)$. All patients located for the study design presented complaints of chronic intractable nonradicular low back pain secondary to disc degeneration, degenerative arthritis in the intervertebral joints and osteophytes, were under physiotherapy treatment and had been previously submitted to a sequence of three weekly caudal blocks with $10 \mathrm{mg}$ of depot-dexamethasone combined with $30 \mu \mathrm{g}$ of clonidine and $40 \mathrm{mg}$ of lidocaine (with added saline to a 10-ml final volume) as part of our routine protocol at the Pain Clinic, two months before the study day. All patients were taken $25-50 \mathrm{mg}$ amitriptyline at bedtime and $20 \mathrm{mg}$ omeprazol in the morning. Oral 100 mg ketoprofen tablet was prescribed as rescue analgesic up to twice daily. However, from the day before the study, no rescue analgesic was allowed, in order to evaluate the analgesic effect of the proposed $\mathrm{T}$ drugs.

The concept of visual analog scale (VAS), which consisted of a $10 \mathrm{~cm}$ line with 0 corresponding to "no pain at all" or "not sedated at all" and 10 to "the worst possible pain" or "most sedated" was introduced before the study. Patients stayed in rest condition in a quiet, temperatureand humidity-controlled room. The study was carried out in the Pain Clinic, in the mornings, with the patient sited in a comfortable long-chair, and the median cephalic or the median basilic vein of the arm was heparinized for blood collection. Although patients complained of daily pain at rest and moving conditions, pain was assessed only during resting state, according to the study protocol.

Each T drug was applied in each arm, in a clean area, and every patient had applied two of the $\mathrm{T}$ preparations, one in the right arm and the other in the left arm, in the right and left deltoid muscles. The effects of $\mathrm{T}$ ketamine $(1 \mathrm{mg} / \mathrm{h}), \mathrm{T}$ clonidine $(25 \mu \mathrm{g} / \mathrm{h})$ or T fentanyl $(25 \mu \mathrm{g} / \mathrm{h})$, combined with $\mathrm{T}$ placebo (CloG, KetG and FenG); or the combination of $\mathrm{T}$ ketamine and clonidine (Ket-CloG), $\mathrm{T}$ fentanyl and ketamine (Fen-KetG), or T fentanyl and clonidine (Fen-CloG) were evaluated (Table 1). One anesthesiologist blind to the treatments applied the $\mathrm{T}$ drugs. The placebo and the $\mathrm{T}$ systems were individually prepared and tested for the pharmacokinetic profile by the Industrial Laboratory of the Faculty of Pharmaceutical Sciences of Ribeirão Preto, Universidade de São Paulo, and contained

\section{TABLE 1 - Groups}

\begin{tabular}{lc}
\hline & $\begin{array}{c}\text { Transdermal system for controlled liberation } \\
\text { of the active drug }\end{array}$ \\
\hline CloG & Placebo + clonidine $25 \mu \mathrm{g} / \mathrm{h}$ \\
KetG & Placebo + ketamine $1 \mu \mathrm{g} / \mathrm{h}$ \\
FenG & Placebo + fentanyl $25 \mu \mathrm{g} / \mathrm{h}$ \\
Ket-CloG & Ketamine $1 \mu \mathrm{g} / \mathrm{h}+$ clonidine $25 \mu \mathrm{g} / \mathrm{h}$ \\
Fen-KetG & Fentanyl $25 \mu \mathrm{g} / \mathrm{h}+$ ketamine $1 \mu \mathrm{g} / \mathrm{h}$ \\
Fen-CloG & Fentanyl $25 \mu \mathrm{g} / \mathrm{h}+$ clonidine $25 \mu \mathrm{g} / \mathrm{h}$ \\
\hline Clo: clonidine; Ket: ketamine; Fen: fentanyl; G: group
\end{tabular}

the same vehicle and similar physical and chemical properties. The dosages chosen for the different $T$ drugs were based on previous experiences with $\mathrm{T}$ ketamine $\mathrm{e}^{5}$ and $\mathrm{T}$ clonidine $^{6}$ and on published data regarding $\mathrm{T}$ fentanyl ${ }^{7}$. The T ketamine cream was developed and tested for controlled delivery of approximately $1 \mathrm{mg} / \mathrm{h}$ ketamine during the study period ${ }^{5}$. Thirty minutes after the $\mathrm{T}$ ketamine application, detectable levels of plasmatic ketamine were observed. By three and six hours, plasma levels of letamine were near 0.05 and $0.08 \mu \mathrm{g} / \mathrm{mL}$, respectively. The T clonidine system was developed to deliver $25 \mu \mathrm{g} / \mathrm{h}$ of the active drug. The process to describe the ideal dose of $\mathrm{T}$ clonidine was carried out in our Pain Clinic. Different IV doses were initially evaluated in patients suffering from chronic pain, and the minor dose that resulted in reduced pain scores was IV $30 \mu \mathrm{g}$ every three hours. Subsequent studies conducted by our group determined that $40 \%$ of the total clonidine dose from the cream preparation was available as plasma free drug. It means that in three hours, although 75 $\mu \mathrm{g}$ of clonidine was disposable through $\mathrm{T}$ application, only $30 \mu \mathrm{g}$ of clonidine (correspondent to $40 \%$ of $75 \mu \mathrm{g}$ ) was available in the plasma, and near $60 \mu \mathrm{g}$ in six-hour evaluation. Related to the $\mathrm{T}$ fentanyl cream, it was developed and tested for controlled delivery of $25 \mu \mathrm{g} / \mathrm{h}$ and, after 3 and 6 hours, its plasma concentration was respectively $0.21 \mathrm{ng} /$ $\mathrm{mL}$ and $0.54 \mathrm{ng} / \mathrm{mL}$.

Pain was evaluated by VAS pain scores $(0-10 \mathrm{~cm})$ and by plasma noradrenalin measurement prior (time $0-\mathrm{h}$ ), 3 hours after (time 3-h) and 6 hours after (time 6-h) the T drugs application. Plasma measurements of noradrenaline were done through High Performance Liquid Chromatography (HPLC) at the Faculty of Pharmaceutical Sciences of Ribeirão Preto, Universidade de São Paulo. After withdraw of 10-mL blood in order to avoid any dilution at the site of collection, $5-\mathrm{ml}$ of venous blood was collected at the times: 1 ) 0 -h (just prior to the T systems application), 2) 3-h and 3) 6-h after T creams application. The samples were transposed in heparinized tubes and plasma separated by centrifugation. The plasma samples were stored at $-70^{\circ} \mathrm{C}$ until drug assay by HPLC. Sedation was evaluated by VAS $(0-10 \mathrm{~cm})$ scores at the times $0-\mathrm{h}, 3-\mathrm{h}$ and 6-h. Mean blood pressure, pulse rate and respiratory frequency were evaluated at 30-minute interval. Pulse oximetry was continuously evaluated, and additional oxygen was available if $\mathrm{O}_{2}$ saturation was inferior to $90 \%$. A 
decrease in mean arterial pressure superior to $15 \%$ below initial baseline was treated by incremental doses of ephedrine, $5 \mathrm{mg}$ IV. Decreases in heart rate below $50 \mathrm{bpm}$ were treated with incremental doses of atropine, $0.5 \mathrm{mg}$ IV. The number of patients having nausea (of any degree) or vomiting at any point was reported. Nausea greater than $4 / 10 \mathrm{~cm}$ at any time or vomiting during the study were treated initially with metoclopramide $10 \mathrm{mg}$ IV followed by ondansetron $4 \mathrm{mg}$ IV, if necessary. Hallucination was treated with incremental IV midazolam. Any other adverse events were noted and treated, if necessary. At the end of the 6-h evaluation, IV 100 mg ketoprofen was available at patient request.

\section{Statistical analysis}

The number of subjects was based on preliminary experimental data. For this pilot study, we hypothesized that $\mathrm{T}$ administration of two drugs combination would enhance by $100 \%$ the analgesic effect of the drug alone, in order to get the best combination among the different drugs. If we would have estimated a standard deviation for this prospective power analysis an $80 \%$ and an $\alpha$ value of 0.05 , these assumptions would have required at least 6 patients in each group to achieve a $100 \%$ decrease in VAS scores.

The normality of the distributions was assessed using the Shapiro-Wilking's test. Groups were compared for demographic data (age, weight, height) and duration of chronic pain by ANOVA. Incidence of adverse events, gender, ASA status and adjuvant drug used were compared between groups by $\chi^{2}$ testcorrected for multiple comparisons. Blood pressure, heart rate, respiratory rate and VAS scores were compared between groups by two-way ANOVA for repeated measures. Tukey analysis was applied to decrease the probability of type I error. The plasma values of noradrenalin and the number of rescue analgesics were compared by means of Kruskal-Wallis test, followed by the Newman-Keuls test, while data within the same group were compared by Friedman test followed by the Wilcoxon rank sum test. The value of $p<0.05$ was considered significant. Data are expressed as mean $\pm \mathrm{SD}$, otherwise stated.

\section{RESULTS}

Fifty-one patients completed the study protocol. One patient from the FenG and one from the Fen-CloG were ex- cluded due to incomplete collected data. A second patient from the Fen-CloG gave up his participation in the middle of the study, for he was in a hurry to get the bus. The six groups showed no differences regarding ASA status, gender, age, weight, height and length in time of pain complaint ( $>0.05$, Table 2). There were no differences concerning mean blood pressure, pulse rate and respiratory frequency measured at 30-min interval among and within groups $(\mathrm{p}>0.05)$. Pulse oximetry was always maintained above $92 \%$ and no patients needed supplemental $\mathrm{O}_{2}$ during the study period.

The data with reference to the pain VAS scores is described in Table 3. The analysis within groups revealed that the VAS pain score at 6-h was smaller compared to the 0 -h to the FenG, CloG, KetG and Ket-CloG $(\mathrm{p}<0.02)$. The groups receiving $\mathrm{T}$ fentanyl combined with either $\mathrm{T}$ ketamine or $\mathrm{T}$ clonidine (Fen-KetG and Fen-CloG) showed a significantly higher improvement between 0 -h and $6-\mathrm{h}(\mathrm{p}<0.01)$. The comparison among groups revealed that all groups were similar at $0-\mathrm{h}$ and 3 -h. At 6-h, both Fen-CloG and Fen-KetG had smaller VAS scores compared to the administration of the correspondent $\mathrm{T}$ drug alone $(\mathrm{p}<0.05$, Table 3$)$.

The plasma noradrenaline data is described in Table 4. The statistical analysis showed that administration of $\mathrm{T}$ fentanyl alone (FenG) resulted in plasma noradrenaline decrease at 6-h compared to itself at 0 -h and $3-h(p<0.01)$, while the association of $\mathrm{T}$ fentanyl with $\mathrm{T}$ clonidine resulted in plasma noradrenaline decrease at 3- and 6-h, compared to itself at $0-\mathrm{h}$ and compared to other groups at $3-\mathrm{h}$ and $6-\mathrm{h}(\mathrm{p}<0.01)$. The combination of both T ketamine and clonidine (Ket-CloG) did not result in a better analgesic profile ( $\mathrm{p}>0.05$ ).

All groups, except the Ket-CloG, were similar regarding adverse effects $(p>0.05)$. One patient from the CloG was sedated (VAS 4-cm), and other complained of heating, sweating, headache and blurred vision at 6-h. The $\mathrm{T}$ drugs were cleaned from the skin and the patients kept in observation for two extra hours. An IV access was obtained and $500 \mathrm{~mL}$ lactate solution was infused during this period. No other pharmacological treatment was necessary and, by the time of discharge, the symptoms had ceased. In the KetG, one patient complained of nausea (VAS 5-cm) at 4-h and was medicated with 10

\section{TABLE 2 - Demographic data}

\begin{tabular}{lcccccc}
\hline & $\begin{array}{c}\text { ASA } \\
(\mathrm{II} / \mathrm{III})\end{array}$ & $\begin{array}{c}\text { Gender } \\
(\mathrm{M} / \mathrm{F})\end{array}$ & $\begin{array}{c}\text { Weight } \\
(\mathrm{kg})^{*}\end{array}$ & $\begin{array}{c}\text { Age } \\
\text { (years) }\end{array}$ & $\begin{array}{c}\text { Height } \\
(\mathrm{cm})^{*}\end{array}$ & $\begin{array}{c}\text { Duration of pain } \\
\text { complaint (years) }\end{array}$ \\
\hline CloG & $6 / 3$ & $2 / 7$ & $72 \pm 17$ & $47 \pm 13$ & $162 \pm 6$ & $7 \pm 2$ \\
KetG & $5 / 4$ & $2 / 7$ & $65 \pm 11$ & $48 \pm 14$ & $160 \pm 7$ & $8 \pm 4$ \\
FenG & $5 / 3$ & $2 / 6$ & $63 \pm 14$ & $51 \pm 18$ & $157 \pm 9$ & $7 \pm 3$ \\
Ket-CloG & $6 / 2$ & $2 / 6$ & $72 \pm 14$ & $41 \pm 14$ & $162 \pm 10$ & $7 \pm 3$ \\
Fen-KetG & $6 / 3$ & $3 / 6$ & $68 \pm 14$ & $42 \pm 13$ & $167 \pm 6$ & $8 \pm 2$ \\
Fen-CloG & $4 / 3$ & $3 / 4$ & $68 \pm 13$ & $46 \pm 7$ & $163 \pm 6$ & $7 \pm 2$ \\
\hline
\end{tabular}

p>0.05; Clo: clonidine; Ket: ketamine; Fen: fentanyl; G: group.

*Data expressed as mean \pm SD. 
TABLE 3 - Visual analogue pain scores (VAS) $0-10 \mathrm{~cm}$ at the study times

\begin{tabular}{lccc}
\hline & 0-hour & 3-hour & 6-hour \\
\hline CloG & $8.6 \pm 1.4$ & $6.6 \pm 2.7$ & $5.2 \pm 2.9^{*}$ \\
KetG & $8 \pm 1$ & $6.1 \pm 1.3$ & $5.1 \pm 0.7^{*}$ \\
FenG & $8 \pm 1.6$ & $7 \pm 2.5$ & $5.4 \pm 2.5^{*}$ \\
Ket-CloG & $7.7 \pm 2$ & $6.6 \pm 2.3$ & $4.9 \pm 2.7^{*}$ \\
Fen-Ket & $7.8 \pm 2.2$ & $5.7 \pm 2.8$ & $3.7 \pm 3.2^{* *+}$ \\
Fen-Clo & $8.1 \pm 1.7$ & $5.7 \pm 2.1$ & $3.2 \pm 2.5^{* *+}$ \\
\hline
\end{tabular}

Data expressed as mean \pm STD.

Clo: clonidine; Ket: ketamine; Fen: fentanyl; G: group

Comparison within groups: ${ }^{*} \mathrm{p}<0.02$ : 0 -h compared to $6-\mathrm{h} ;{ }^{* *} \mathrm{p}<0.01$ : $0-\mathrm{h}$ compared to 6-h

Comparison among groups; all groups were similar at $0-h$ and $3-h ;{ }^{+} p<0.05$ : Fen-KetG and Fen-CloG-6-h compared to CloG, KetG and FenG.

\begin{tabular}{|c|c|c|c|}
\hline & 0-hour & 3-hour & 6-hour \\
\hline CloG & $2.3 \pm 0.4$ & $2.4 \pm 0.4$ & $2.4 \pm 0.4$ \\
\hline KetG & $2.3 \pm 0.5$ & $2.2 \pm 0.3$ & $2.6 \pm 0.5$ \\
\hline FenG & $2.5 \pm 0.4$ & $2.4 \pm 0.5$ & $1.7 \pm 0.2^{*}$ \\
\hline Ket-CloG & $2.4 \pm 0.4$ & $2.3 \pm 0.4$ & $2.2 \pm 0.4$ \\
\hline Fen-KetG & $2.4 \pm 0.5$ & $2.3 \pm 0.5$ & $2.6 \pm 0.5$ \\
\hline Fen-CloG & $2.4 \pm 0.3$ & $1.6 \pm 0.2^{*+}$ & $1.5 \pm 0.2^{*+}$ \\
\hline
\end{tabular}

Data expressed as mean \pm SD.

Clo: clonidine; Ket: ketamine; Fen: fentanyl; G: group.

Comparison within groups: ${ }^{*} \mathrm{p}<0.01$; FenG: 6-h compared to 0 -h and 3-h; Fen-CloG: 3-h compared to 0 -h and 6-h compared to $0-h$;

Comparison among groups; ${ }^{+} p<0.01$ : Fen-CloG at both $3-h$ and $6-h$, compared to the other groups at 3-h and 6-h.

mg IV metoclopramide. In the FenG, no adverse effects were observed during the study period. Two patients from the Ket-FenG were mildly sedated at 6-h (VAS $2-\mathrm{cm})$. One patient from the Fen-CloG complained of transitory nausea (VAS 3-cm) at 4-h, but no pharmacological treatment was necessary. No other adverse effects were noted.

The group Ket-Clo was statistically different concerning the sedation $(p<0.02)$. Seven among nine patients were sedated by 6 -h (VAS $5-8 \mathrm{~cm}$ ), although respiratory frequency and pulse oximetry did not differ within and among groups. One of the patients complained about headache at 3-h, hence $100 \mathrm{mg}$ IV ketoprofen was infused over 20-min. Another patient had hypertension (150/95 $\mathrm{mmHg}$ ) at $6-\mathrm{h}$, and the $\mathrm{T}$ drugs were cleaned from the skin of both arms. The patient was kept in close observation and blood pressure measured at 5-min interval for an extra 45-min, when blood pressure was 138/83 $\mathrm{mmHg}$. She had no clinical discomfort during this period. There were no complaints of hallucination or other adverse effects from patients.

\section{DISCUSSION}

The results of the actual study demonstrated that any $\mathrm{T}$ drug alone resulted in clinical analgesia based on the smaller pain VAS scored at 6-h, and that combination of $\mathrm{T}$ fentanyl with either $\mathrm{T}$ ketamine or $\mathrm{T}$ clonidine resulted in even smaller pain VAS scores at 6-h in comparison to the administration of the correspondent $\mathrm{T}$ drug alone. The analgesia following $\mathrm{T}$ fentanyl, in accordance to other studies $^{7}$, was further corroborated by decrease of plasma noradrenaline levels, when applied alone or combined with T clonidin.

The literature reveals that opioids are commonly prescribed for chronic back pain and may be efficacious for short-term pain relief, as long-term efficacy for up to 16 weeks is unclear. In addition, substance use disorders are common in patients who take opioids for back pain, and aberrant medication-taking behaviors occurred in up to $24 \%$ of the cases ${ }^{8}$. Among opioids, T fentanyl was described as superior to oral morphine for chronic low back pain. Although daily analgesia was similar between the two opioids, $\mathrm{T}$ fentanyl resulted in less constipation and greater pain relief at night ${ }^{9}$. The drugs of the study were chosen based on actual data regarding pain processes. Inotropic NMDA receptors play a crucial role at pain pathways, and their modulation may have potential for therapeutic utility in categories of persistent pain, including neuropathic, inflammatory or joint-related pain ${ }^{1}$ that may contribute to low back pain. Ketamine would act by antagonizing the NMDA receptor and expression patterns in nociceptive pathways ${ }^{1}$. The second drug studied, the $\alpha 2$-agonist clonidine, was described to exert analgesia by depressing the synaptic plasticity in spinal dorsal horn, via activation of muscarinic receptor-NO-cGMP pathway ${ }^{2}$ and, finally, the participation of opioids in central plasticity is well know ${ }^{10}$.

However, although clinical evaluation revealed to some extent benefit of all $\mathrm{T}$ drugs tested, the laboratorial data revealed that administration of $\mathrm{T}$ fentanyl alone (FenG) resulted in plasma noradrenaline decrease at 6-h compared to itself at the $0-\mathrm{h}$. Although the minimum effective concentration of $T$ fentanyl in serum $(0.63 \mathrm{ng} / \mathrm{mL})$ was achieved at $11.3 \pm 4.9$ hours after application ${ }^{11}$, fentanyl as a cream preparation took less than six hours, and was indirectly supported by the decreased plasma noradrenaline serum levels. In addition, the association of T fentanyl with clonidine resulted in plasma noradrenaline decrease even at 3- and 6-h, compared to either drug alone or to the other groups, corroborating to the clinical data. It has been demonstrated that stress-produced hormones (such as noradrenaline) in the blood serum served as indirect criteria of the functional activity of the endogenic antinociceptive structures before and after the treatment $t^{4}$. It is a fact that interaction of adrenoreceptors with $\alpha$-opioids is clear in inflammation, and that endogenous $\alpha(2)$-adrenergic systems play an important role in the modulation of the effectiveness of opioids during inflammation process ${ }^{12}$, what could explain the actual results. However, patients who received 
only $\mathrm{T}$ clonidine (CloG) did not show any decrease in plasma noradrenaline levels. Although $\alpha 2$-adrenergic receptor activation with clonidine in rats experiencing hyperalgesia inhibited noradrenaline release $\mathrm{e}^{13}$, and clonidine resulted in dose-dependent noradrenaline decrease ${ }^{14}$, by 6-h evaluation the dose used resulted in no evident decrease of noradrenaline by itself. However, the same dose further enhanced nordrenaline decrease after $T$ fentanyl at 3-h evaluation.

In the present study, the combined administration of the opioid fentanyl and ketamine resulted in analgesia by $6-\mathrm{h}$, which was evidenced by lower VAS pain scores compared to $\mathrm{T}$ application of one of the study' drugs alone. In accordance, metabotropic glutamate receptors and morphine demonstrated to possess synergistic drug interaction for antinociception during phase 2 in the formalin test in rats ${ }^{15}$. The application of $\mathrm{T}$ ketamine alone (KetG) was analgesic by itself, in accordance to others ${ }^{16}$, and result in greater plasma noradrenaline levels, but apparently blunted the decrease in the Fen-KetG at 6-h. The absence of any decrease in plasma noradrenaline level was probably secondary to ketamine. Ketamine induces sympathomimetic action by impairment of both exocytosis and noradenaline uptake ${ }^{17}$, plasma noradrenaline increased by $20 \%$ after bolus IV injection of ketamine in volunteers ${ }^{18}$ and, in dogs, while ketamine used alone caused increased noradrenaline concentration, the association of the $\alpha 2$-agonist medetomidine prevented or blunted this change ${ }^{19}$. By the time, cortisol levels were not measured, as patients received cumulative depotdexamethasone, which may have compromised the hypothalamic-pituitary axis. Besides, plasma cortisol serum concentration was described as similar regarding healthy control and chronic low back pain ${ }^{20,21}$.

Interestingly, the combination of both $\mathrm{T}$ ketamine and clonidine (Ket-CloG) did not result in a better analgesic profile compared to the correspondent drug alone and resulted in excessive sedation during the 6-h evaluation. The data demonstrated that the combined administration of ketamine and clonidine did not enhance analgesia, but enhanced adverse effects, which was disappointing to us. The rate of opioid prescription in our practice for chronic noncancerous pain is less than 5\%, as we are among the Pain Specialists that do not approve opioids as first-line therapy in nonmalignant chronic pain, and there was some degree of expectative regarding the combination of ketamine and clonidine as the "best association" for this purpose. This pilot study was indeed conducted and limited to duration of assessment of 6 hours because of our interest in defining the best drugs association in order to direct us for future and long-time evaluation studies, and our greatest expectation was indeed the among non-opioid drugs ketamine and clonidine. In the mouse hot plate-test, the potency of clonidine was found to increase with co-administration of ketamine, but not dextromethorphan ${ }^{22}$. Although this association was controversial in acute pain ${ }^{23-25}$, the continuous intrathecal administration of $\mathrm{S}(+)$-ketamine with clonidine resulted in adequate pain relief in a patient suffering from intractable neuropathic cancer pain ${ }^{26}$. In the current study, a pure placebo group was not included, what could theoretically affect the decrease in the VAS scores clinically obtained, but could not have blunted the noradrenaline serum data found.

In conclusion, all studied drugs resulted in clinical analgesia (VAS) at 6-h, and the association of fentanyl with either clonidine or ketamine resulted in even smaller VAS scores in comparison to the drugs alone. However, $\mathrm{T}$ fentanyl analgesia was corroborated by lower plasma noradrenaline levels at 6-h when applied alone, or at 3-h when combined with $\mathrm{T}$ clonidine in patients suffering from chronic low back pain. Whether the mechanism of action is central, peripheral, or both, is something that could not be determined based on these data.

\section{REFERENCES}

1. Shyu BC, Vogt BA. Short-term synaptic plasticity in the nociceptive thalamic-anterior cingulate pathway. Mol Pain. 2009;5(1):51-4.

2. Ge YX, Xin WJ, Hu NW, Zhang T, Xu JT, Liu XG. Clonidine depresses LTP of C-fiber evoked field potentials in spinal dorsal horn via NO-cGMP pathway. Brain Res. 2006;1118(1):58-65.

3. Lauretti GR. Highlights in opioid agonists and antagonists. Expert Rev Neurother. 2006;6(4):613-22.
4. Nechipurenko NI, Dudina TV, Elkina AI, Elkin IuB. Pathogenetic basis for the use of GABA-ergic preparations in combination with atropine during chronic pain syndrome in patients with neurologic manifestations of lumbar osteochondrosis. Vopr Med Khim. 2000;46(1):36-42.

5. Azevedo VM, Lauretti GR, Pereira NL, Reis MP. Transdermal ketamine as an adjuvant for postoperative analgesia after abdominal gynecological surgery using lidocaine epidural blockade. Anesth Analg. 2000;91(6):1479-82.
6. Kang H, Zhang YF, Jiao FY, Guo $\mathrm{XY}$, Gao XM. Efficacy of clonidine transdermal patch for treatment of Tourette's syndrome in children. Zhongguo Dang Dai Er Ke Za Zhi. 2009;11(7):537-9.

7. Benrath J, Brechtel C, Martin E, Sandkühler J. Low doses of fentanyl block central sensitization in the rat spinal cord in vivo. Anesthesiology. 2004;100(6):1545-51.

8. Martell BA, O'Connor PG, Kerns RD, Becker WC, Morales KH, Kosten TR, et al. Systematic review: opioid treatment for chronic back pain: prevalence, efficacy, and association with addiction. Ann Intern Med. 2007;146(2):116-27. 
9. Allan L, Richarz U, Simpson K, Slappendel R. Transdermal fentanyl versus sustained release oral morphine in strong-opioid naive patients with chronic low back pain. Spine (Phila Pa 1976). 2005;30(22):2484-90.

10. Suzuki R, Porreca F, Dickenson AH. Evidence for spinal dorsal horn hyperexcitability in rats following sustained morphine exposure. Neurosci Lett. 2006;407(2):156-61.

11. Siafaka I, Rellia P, Argyra E, Iakovidou N, Sykiotis C, Vadalouka A. Pharmacokinetic profile and efficacy of a fentanyl transdermal delivery system for acute postoperative pain after intraabdominal gynecologic surgery for cancer. Pain Pract. 2004;4(2):98104.

12. Herrero JF, Solano RE. The antinociceptive effect of the muopioid fentanyl is reduced in the presence of the alpha(2)-adrenergic antagonist idazoxan in inflammation. Brain Res. 1999;840(1-2):106-14.

13. Spengler RN, Sud R, Knight PR, Ignatowski TA. Antinociception mediated by alpha(2)-adrenergic activation involves increasing tumor necrosis factor alpha (TNFalpha) expression and restoring TNFalpha and alpha(2)-adrenergic inhibition of norepinephrine release. Neuropharmacology. 2007;52(2):576-89.

14. Mizobe T, Nakajima Y, Sunaguchi M, Ueno H, Sessler DI. Clonidine produces a dose-dependent impairment of baroreflex-mediated thermoregulatory responses to positive end-expiratory pressure in anaesthetized humans. Br J Anaesth. 2005;94(4):536-41.
15. Yoon MH, Choi J, Bae HB, Kim SJ, Chung ST, Jeong SW, et al. Antinociceptive effects and synergistic interaction with morphine of intrathecal metabotropic glutamate receptor 2/3 antagonist in the formalin test of rats. Neurosci Lett. 2006;394(3):222-6.

16. Zapantis G, Csóka I, Csányi E, Horváth G, Erös I. Evaluation of ketamine systemic absorption from topical preparations. Short Communication. Acta Biol Hung. 2006;57(3):387-9.

17. Kitagawa H, Yamazaki T, Akiyama T, Mori H, Sunagawa K. Effects of ketamine on exocytotic and nonexocytotic noradrenaline release. Neurochem Int. 2003;42(3):261-7.

18. Morse Z, Sano K, Kanri T. Effects of a propofol--ketamine admixture in human volunteers. Pac Health Dialog. 2003;10(1):51-4.

19. Ambrisko TD, Hikasa Y, Sato $\mathrm{K}$. Influence of medetomidine on stress-related neurohormonal and metabolic effects caused by butorphanol, fentanyl, and ketamine administration in dogs. Am J Vet Res. 2005;66(3):406-12.

20. Lentjes EG, Griep EN, Boersma JW, Romijn FP, de Kloet ER. Glucocorticoid receptors, fibromyalgia and low back pain. Psychoneuroendocrinology. 1997;22(8):603-14.

21. Sudhaus S, Fricke B, Schneider S, Stachon A, Klein H, von Düring $\mathrm{M}$, et al. The cortisol awakening response in patients with acute and chronic low back pain: relations with psychological risk factors of pain chronicity. Schmerz. 2007;21(3):206-11.
22. Baker AK, Hoffmann VL, Meert TF. Interactions of NMDA antagonists and an alpha 2 agonist with mu, delta and kappa opioids in an acute nociception assay. Acta Anaesthesiol Belg. 2002;53(3):203-12.

23. Lauretti GR, Rodrigues AM, Paccola CA, Mattos AL. The combination of epidural clonidine and $\mathrm{S}(+)$-ketamine did not enhance analgesic efficacy beyond that for each individual drug in adult orthopedic surgery. J Clin Anesth. 2005;17(2):79-84.

24. Passariello M, Almenrader N, Canneti A, Rubeo L, Haiberger R, Pietropaoli P. Caudal analgesia in children: $\mathrm{S}(+)$-ketamine vs $\mathrm{S}(+)-$ ketamine plus clonidine. Paediatr Anaesth. 2004;14(10):851-5.

25. Hager H, Marhofer P, Sitzwohl C, Adler L, Kettner S, Semsroth $\mathrm{M}$. Caudal clonidine prolongs analgesia from caudal $\mathrm{S}(+)-$ ketamine in children. Anesth Analg. 2002;94(5):1169-72.

26. Vranken JH, Troost D, Wegener JT, Kruis MR, van der Vegt MH. Neuropathological findings after continuous intrathecal administration of $\mathrm{S}(+)$-ketamine for the management of neuropathic cancer pain. Pain. 2005;117(1-2):231-5.

\section{Correspondence}

Gabriela Rocha Lauretti

Rua Maestro Joaquim Rangel, 644

CEP 14025-610 - Ribeirão Preto (SP), Brazil

Fone: (16) 3602-2211

E-mail: grlauret@fmrp.usp.br 